Ann. rheum. Dis. (1964), 23, 163.

\title{
EFFECT OF HYDROCORTISONE ON THE UTILIZATION OF TRITIATED THYMIDINE FOR SKELETAL GROWTH IN THE RAT
}

\author{
BY \\ M. H. YOUNG AND W. A. J. CRANE \\ Department of Pathology, University of Sheffield
}

Thymidine is a specific precursor of deoxyribonucleic acid (DNA) and is utilized for chromosomal replication by the nuclei of cells when they double their DNA content in interphase before cell division (Reichard and Estborn, 1951; Friedkin, Tilson, and Roberts, 1956; Gall and Johnson, 1960; Mirsky and Osawa, 1961). Autoradiography after the administration of thymidine labelled with tritium ( ${ }^{3} \mathrm{H}$-thymidine) to experimental animals is now established as a valuable tracer of DNA synthesis in actively dividing cells, for the energy of the beta radiation emitted by tritium $(0.018 \mathrm{MeV})$ is sufficiently low to allow precise localization of the label in single nuclei that are preparing to divide. Furthermore, the time taken for DNA synthesis is considerably longer than that required for actual nuclear division, so that a ${ }^{3} \mathrm{H}$-thymidine labelling index becomes a more sensitive indicator of cell renewal and proliferation than conventional assessments of the mitotic index (Cronkite, Bond, Fliedner, and Rubini, 1959; Leblond, Messier, and Kopriwa, 1959; Crane and Dutta, 1963). In the experiments described in this paper, we have used this technique to identify the various cells in normal rat skeletal tissues that utilize labelled thymidine and have measured the depression in the labelling index that results from treatment with hydrocortisone.

\section{Material and Methods}

The experiments were carried out on male inbred albino rats in the range $170-190 \mathrm{~g}$. body weight and maintained on an unrestricted commercial pellet diet. Six rats served as normal controls and eight were given hydrocortisone acetate $5 \mathrm{mg}$. subcutaneously each morning for 28 days. At the end of this period the animals were given an intraperitoneal injection of ${ }^{3} \mathrm{H}$-thymidine (thymidine-6-T nominal, obtained from the Radiochemical Centre, Amersham) at a dose level of $1 \mu \mathrm{c}$. per $\mathrm{g}$. body weight. They were killed 4 hours later by exsanguination under ether anaesthesia. In every instance the labelled nucleoside was injected at 10 a.m. and the rats were killed at 2 p.m. in order to avoid any alteration in uptake associated with diurnal variations in mitotic rhythm and DNA synthesis.

The right knee joint, with about $8 \mathrm{~mm}$. of the lower end of the femur and a similar length of the upper tibia, was removed and fixed in 4 per cent. neutral formaldehyde. After fixation the specimens were decalcified with ethylenediamine tetra-acetic acid (EDTA) and processed to paraffin. Four sagittal sections $7 \mu$ thick were serially cut through the centre of each joint. One was routinely stained with haematoxylin and eosin and the remainder were used for autoradiography.

Autoradiographs were prepared with fine-grain stripping film from Kodak AR10 plates and were exposed at $4^{\circ} \mathrm{C}$. for 6,12 , and 19 weeks in a dry atmosphere; after development in Kodak D19b developer, they were stained through the film with 1 per cent. aqueous neutral red. Accurate nuclear localization of the tritium label was observed in all the autoradiographs, but the more dense image achieved in the 19-week preparations proved best for detailed counts of labelled and non-labelled nuclear populations.

\section{Results}

Structural abnormalities were consistently observed in the epiphyseal growth plate and metaphysis of the rats given hydrocortisone. Elsewhere there were no histological differences between the experimental groups, but a difference in the capacity to utilize ${ }^{3} \mathrm{H}$-thymidine was revealed by the autoradiographs. 


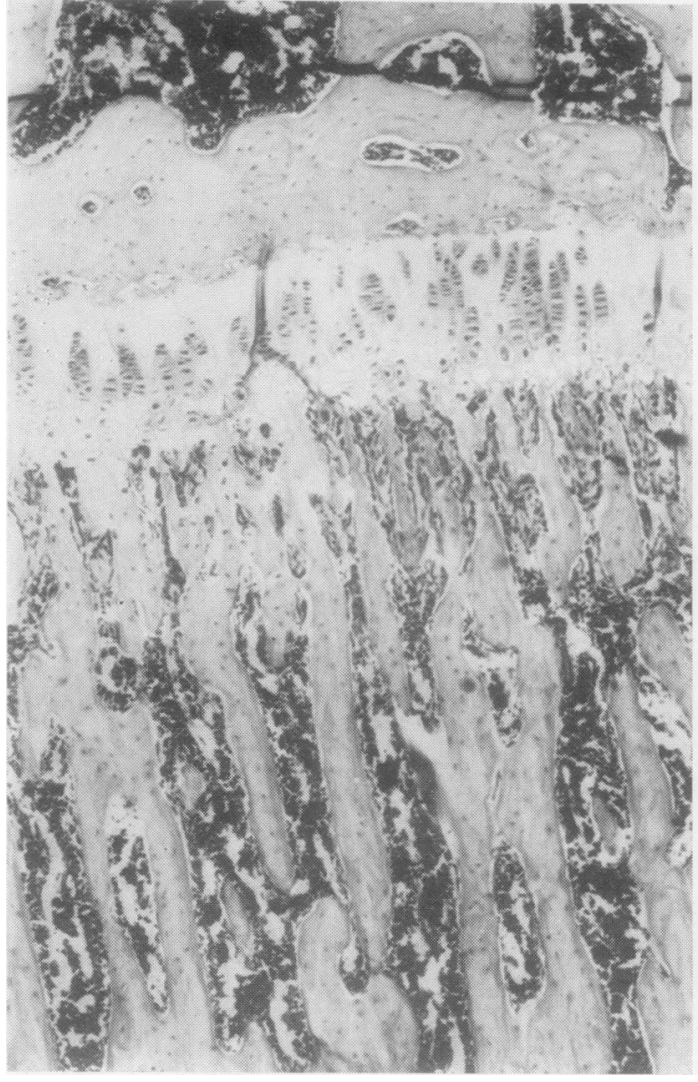

Fig. 1.-Proximal tibial growth plate of a normal rat. Haematoxylin and eosin, $\times 50$.

Epiphyseal Growth Plate.-Treatment with hydrocortisone reduced the width of the femoral and tibial growth plates to about one half normal thickness (cf. Figs 1 and 2). A detailed study was made of the tibial growth plate only and the results are shown in Table I.

The average number of cells, labelled and nonlabelled, per growth column in normal rats (Fig. 3,

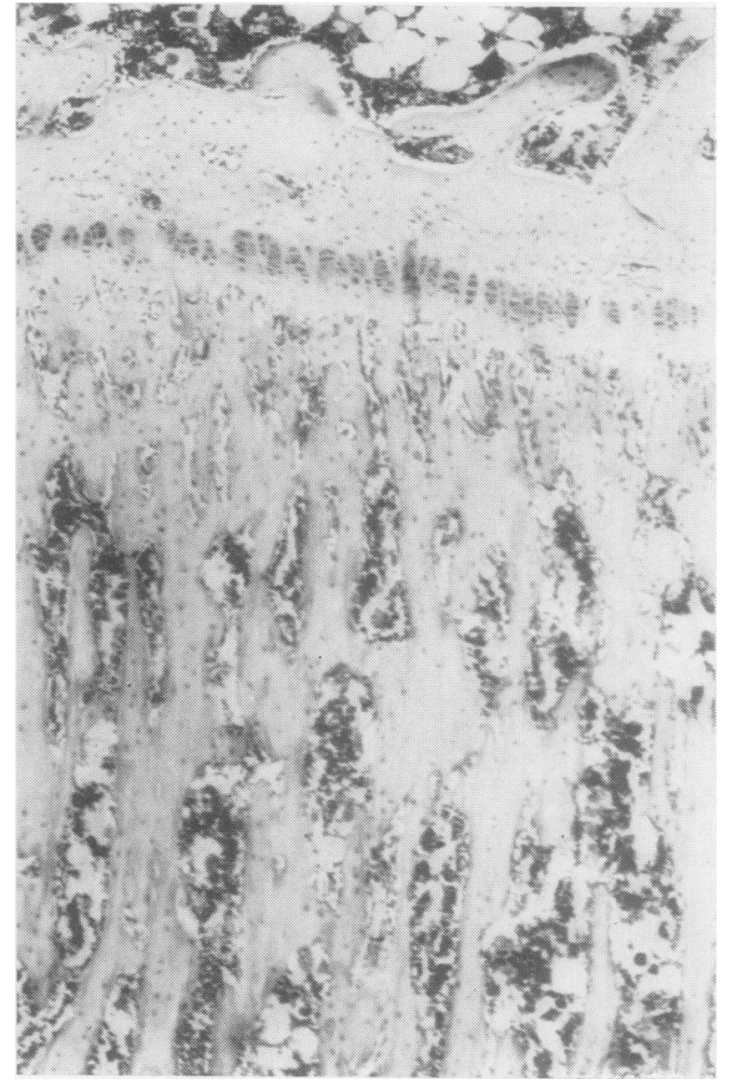

Fig. 2.-Proximal tibial growth plate of a hydrocortisone-treated rat. The growth plate is thinner and there is less marrow than normal in the metaphysis. Cf. Fig. 1. Haematoxylin and eosin, $\times 50$.

opposite) ranged from $9 \cdot 2$ to $14 \cdot 1$ (mean $11 \cdot 7$ ). The administration of hydrocortisone caused a significant reduction in the population of cells per column (mean $8.85 ; \mathrm{P}<0.01$ ). This reduced number of cells contributed to the thinning of the growth plates induced by hydrocortisone, but additional factors were the diminution in the amount of matrix and closer packing of the cells per column. Examination

TABLE I

CHARACTERISTICS OF CELL POPULATION AND ${ }^{3}$ H-THYMIDINE UPTAKE IN THE EPIPHYSEAL GROWTH PLATE OF NORMAL AND HYDROCORTISONE-TREATED RATS

\begin{tabular}{|c|c|c|c|c|c|c|}
\hline Group & $\begin{array}{c}\text { No. of } \\
\text { Rats }\end{array}$ & $\begin{array}{l}\text { Total } \\
\text { Nuclei }\end{array}$ & $\begin{array}{l}\text { No. of Growth } \\
\text { Columns }\end{array}$ & $\begin{array}{l}\text { Average No. of } \\
\text { Cells per Column }\end{array}$ & $\begin{array}{c}\text { Total Labelled } \\
\text { Nuclei }\end{array}$ & $\begin{array}{l}\text { Labelling } \\
\text { Index }\end{array}$ \\
\hline $\begin{array}{l}\text { Normal } \\
\text { Hydrocortisone }\end{array}$ & $\begin{array}{l}6 \\
8\end{array}$ & $\begin{array}{r}1.050 \pm 85 \\
945 \pm 37\end{array}$ & $\begin{array}{r}91 \pm 6 \cdot 8 \\
107 \pm 4 \cdot 6\end{array}$ & $\begin{array}{l}11 \cdot 7 \pm 0 \cdot 88 \\
8 \cdot 85 \pm 0 \cdot 25^{*}\end{array}$ & $\begin{array}{l}82 \pm 10 \cdot 5 \\
22 \pm 5 \cdot 2\end{array}$ & $\begin{array}{l}0.08+0.013 \\
0.023=0.005\end{array}$ \\
\hline
\end{tabular}




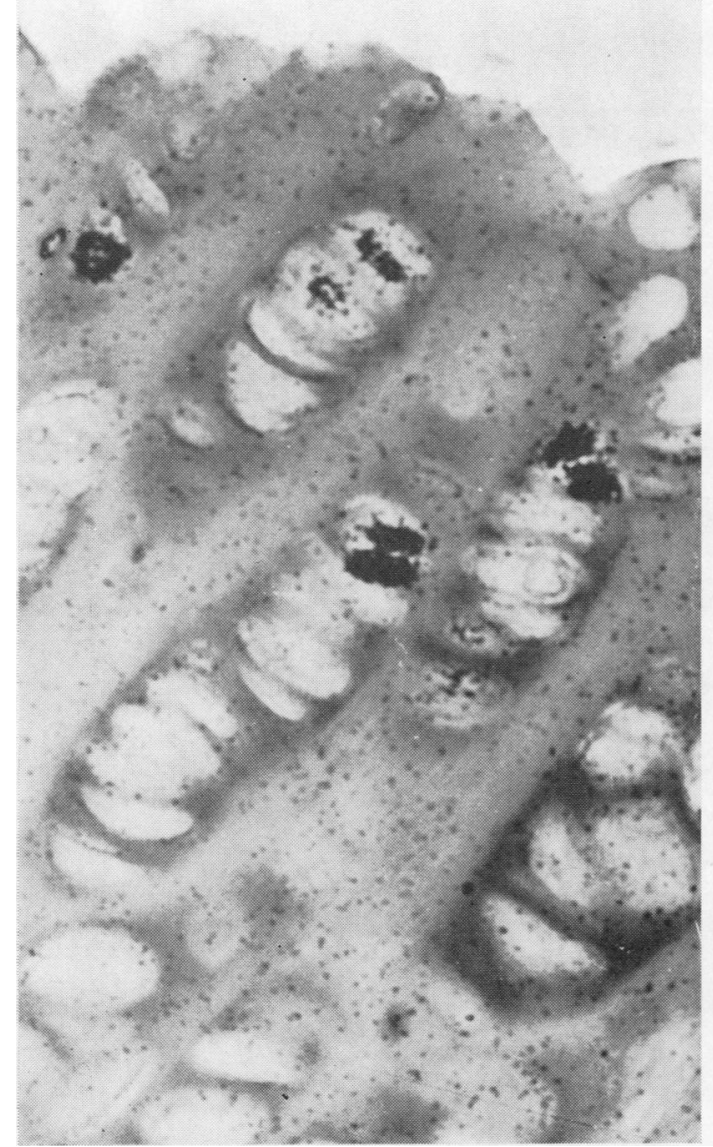

Fig. 3.-Proximal tibial growth plate of a normal rat showing labelled nuclei in the growth columns. Autoradiograph, counterstained neutral red, $\times 500$.

of the autoradiographs showed that hydrocortisone caused a reduction in the number of radioactive growth plate nuclei and this was confirmed by measurements of the labelling index (labelling index $=$ ratio labelled nuclei : total nuclei). The range for the normal growth plates was 0.055 to 0.134 (mean 0.08 ) compared with a range of 0.005 to 0.044 (mean 0.023 ) in the rats treated with hydrocortisone. This difference is statistically highly significant $(\mathrm{P}<0.001)$.

Metaphysis.-The metaphysis in the hydrocortisone-treated rats was less cellular than in the normal animals. The bars of provisional cancellum were thicker and contained larger fragments of unresorbed cartilage matrix. All the cells were counted in a strip of metaphysis $0.2 \mathrm{~mm}$. deep and $2 \mathrm{~mm}$. wide lying transversely and immediately adjacent to the growth plate. In counting no attempt was made to

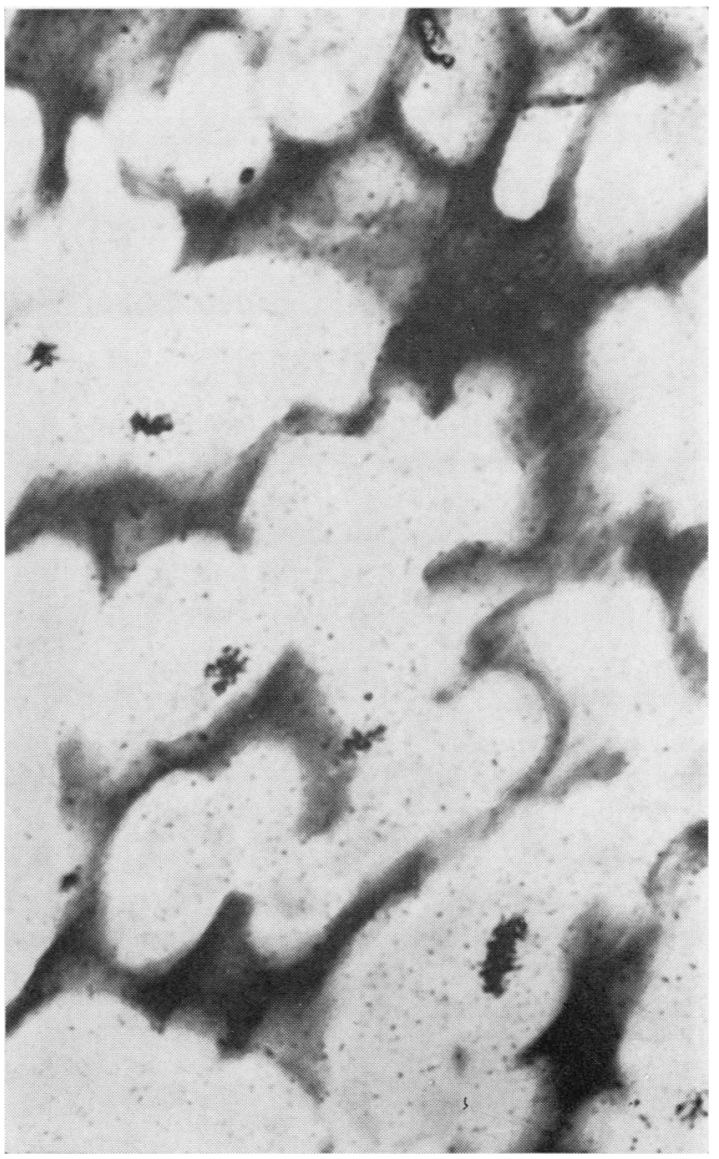

Fig. 4.-Labelled nuclei in proximal metaphysis of normal rat tibia. Autoradiograph, counterstained neutral red, $\times 500$.

differentiate the various types of cell in the population, for so many are of intermediate or indeterminate character (Fig. 4). The results confirmed that the overall cellularity of this region in the hydrocortisone-treated rats was significantly lower (P $<0.001$ ) than in the normal rats (Table II, overleaf).

When, however, the number of labelled nuclei was measured and the metaphyseal labelling index calculated, no difference was observed between the groups. The value of 0.077 obtained in normal rats closely approximated the figure of 0.08 derived from the animals given hydrocortisone $(P>0 \cdot 8)$. It would appear, therefore, that the capacity to utilize ${ }^{3} \mathrm{H}$-thymidine for DNA synthesis by the metaphyseal cells was unaltered at the end of 28 days' hydrocortisone treatment, but this was a most heterogeneous cell population and we have not attempted to measure the labelling indices in the individual cell 
TABLE II

CHARACTERISTICS OF CELL POPULATION AND ${ }^{3}$ H-THYMIDINE UPTAKE IN THE METAPHYSIS, ARTICULAR CARTILAGE AND SYNOVIAL MEMBRANE OF NORMAL AND HYDROCORTISONE-TREATED RATS

\begin{tabular}{|c|c|c|c|c|c|c|c|c|}
\hline \multirow{2}{*}{ Group } & & \multirow{2}{*}{$\begin{array}{l}\text { No. of } \\
\text { Rats }\end{array}$} & \multicolumn{4}{|c|}{ Metaphysis } & \multirow{2}{*}{$\begin{array}{l}\text { Articular } \\
\text { Cartilage } \\
\text { Labels }\end{array}$} & \multirow{2}{*}{$\begin{array}{c}\text { Synovial } \\
\text { Membrane } \\
\text { Labels }\end{array}$} \\
\hline & & & $\begin{array}{l}\text { Nuclei per } \\
0.4 \mathrm{~mm} .^{2}\end{array}$ & $\begin{array}{c}\text { Labelled Nuclei } \\
\text { per } 0.4 \mathrm{~mm} .^{2}\end{array}$ & $\begin{array}{l}\text { Labelling } \\
\text { Index }\end{array}$ & $\begin{array}{l}\text { Osteoclasts } \\
\text { per } 0.4 \mathrm{~mm} .^{2}\end{array}$ & & \\
\hline $\begin{array}{l}\text { Normal . . } \\
\text { Hydrocortisone }\end{array}$ & $\begin{array}{l}\cdots \\
\cdots\end{array}$ & $\begin{array}{l}6 \\
8\end{array}$ & $\begin{array}{l}2,025 \pm 56 \\
1,132 \pm 65^{*}\end{array}$ & $\begin{array}{r}155 \pm 14 \cdot 3 \\
91 \pm 14 \cdot 1\end{array}$ & $\begin{array}{l}0.077 \pm 0.012 \\
0.08 \pm 0.009 \dagger\end{array}$ & $\begin{array}{l}6 \pm 1 \cdot 2 \\
5 \cdot 5 \pm 0 \cdot 9\end{array}$ & $\begin{array}{l}3 \cdot 5 \pm 1 \cdot 4 \\
0 \cdot 88 \pm 0 \cdot 35\end{array}$ & $\begin{array}{l}3.6 \pm 0.92 \\
0.5 \pm 0.06\end{array}$ \\
\hline
\end{tabular}

The figures given are means \pm standard error

$* P<0.001 \quad+\mathrm{P}>0.8$

groups. In view of the apparent impairment of cartilage absorption in the rats given hydrocortisone, osteoclasts were counted in the strip of metaphysis previously defined. These large multinucleated cells may be identified with confidence. The mean count was six cells in the normal metaphysis, compared with 5.5 cells after hydrocortisone. These figures do not explain the impairment of cartilage absorption in hydrocortisone-treated rats. It may be that bone and cartilage absorption is not solely a function of multinucleated giant cells and that cells morphologically resembling osteoblasts also possess this function (Dodds, 1932).

Articular Cartilage.-There were no obvious differences on comparing routine sections of articular cartilage from the normal and hydrocortisonetreated rats, but the autoradiographs showed a difference in chondrocyte labelling. The incidence of nuclear labelling in articular cartilage was much lower than in epiphyseal growth cartilage. The total number of radioactive nuclei in both the femoral and tibial articular cartilage was counted in each specimen, but the labelling index was not calculated. The results are shown in Table II. Although there was some overlap, in general there were fewer labelled nuclei in the hydrocortisone-treated group (mean 0.88 ) than in the normal animals (mean 3.5 ).

Synovial Lining.-The periarticular connective tissues were not studied in detail, attention being focused on the lining layer of synovial membrane. The results were similar to those obtained for the articular cartilage, in that although no difference was detected in ordinary histological preparations a different incidence in nuclear labelling was found in the two groups. Labelled synovial nuclei were much less frequent in the hydrocortisone-treated animals (mean $0 \cdot 5$ ) than in normal rats (mean $3 \cdot 6$ ).

Mature Bone.-No labels were identified in the nuclei of osteocytes in any of the autoradiographs and no structural difference was observed on comparing mature bone from the normal rats with those given hydrocortisone.

\section{Discussion}

The development of high resolution autoradiography and the availability of a variety of nucleic acid precurors has greatly facilitated studies of the nature and magnitude of cell proliferation in many tissues. Most investigations have been carried out with ${ }^{3} \mathrm{H}$-thymidine because it can be used to advantage as a pulse- or flash-label since it is available for nuclear DNA replication for only a limited period (10-30 min.) after injection (Rubini, Cronkite, Bond, and Fliedner, 1960; Wimber, 1963). By this means the number of cells in the DNA synthetic phase ( $S$ phase of the nuclear cycle: Howard and Pelc, 1953) can be accurately assessed in animals killed shortly after injection of the labelled nucleoside.

Our results with this method of ${ }^{3} \mathrm{H}$-thymidine labelling illustrate the various cell types in the osseous and articular tissues of the normal young rat that are synthesizing DNA preparatory to nuclear division and give some estimation of the cell numbers concerned. One of the sites of most active cell proliferation involves the chondrocytes of the epiphyseal growth plate and in this respect the results agree with those of Kember (1960) on the rat and of Tonna (1961) on the mouse. Labelled nuclei were also identified in chondrocytes of the articular cartilage and in synovial lining cells, but the proportion of radioactive nuclei in these tissues was much reduced compared with growth plate nuclei. Labelled osteoblasts or osteoclasts were not identified with complete certainty in the mixed population of metaphyseal cells in the present study, but they were observed by Kember (1960) in a more extended investigation of endochondral ossification and bone growth in the normal rat. His material comprised autoradiographs from rats killed $1 \mathrm{hr}$ to 28 days after injection of ${ }^{3} \mathrm{H}$-thymidine and further preparations from animals given repeated injections of the labelled nucleoside. From these studies it was possible to calculate the approximate mean values for the mitotic time and DNA synthetic time of growth plate chondrocytes at $41 \mathrm{~min}$. and $8.5 \mathrm{hrs}$ respectively. 
In the present experiments we have been particularly concerned with the alterations in the cell proliferative pattern that follow hydrocortisone treatment in the rat. The wide use of this steroid in the therapy of rheumatoid disorders has stimulated many experimental investigations of its effect on bone and cartilage growth, and the morphological changes that we describe are similar to those reported by Follis (1951), Laron and Boss (1962), and other workers. The growth plate was narrowed and the metaphysis became more dense and less cellular. It is well established that cortisone and hydrocortisone have a depressant effect on mitotic activity in many different tissues. Ghadially and Green (1957), for example, studied this in mouse epidermis where cells in mitosis are normally abundant. Our results show that hydrocortisone also depresses the DNA synthetic phase of the nuclear cycle, and furthermore it is clear that the thymidine autoradiographic technique is sufficiently sensitive to permit reasonable measurements of this hydrocortisone effect even when the normal labelling rate is low, for a reduction in labelling was the only change observed in articular cartilage and the synovial membrane, both of which have low cell-turnover rates in the normal rat.

Hydrocortisone caused a significant decrease both in the number of growth plate nuclei utilizing ${ }^{3} \mathrm{H}$-thymidine and in the number of cells in the growth columns. The epiphyseal growth plate was reduced to about half the normal thickness and the alterations in labelling rates and cell population appeared to account for at least part of this reduction. As well as the decrease in the average number of cells per growth column, however, the other factors that contributed to growth plate thinning included a narrowing of the zone of hypertrophied cells and an overall diminution in the amount of cartilage matrix. There is little doubt that the matrix changes represent a further effect of hydrocortisone on chondrocyte function characterized by a reduced capacity to synthesize chondroitin sulphate. The present experiments provide no information on this aspect, but it has been repeatedly shown that cortisone and hydrocortisone reduce the level of incorporation of ${ }^{35} \mathrm{~S}$-sulphate by chondrocytes into the sulphated acid mucopolysaccharides of cartilage (Duthie, 1962; Hulth and Westerborn, 1963 ; and other workers).

The morphological changes induced by hydrocortisone in the metaphysis appeared to be consequent upon an impairment in the process of cartilage resorption. The metaphysis was the one area studied in which the level of ${ }^{3} \mathrm{H}$-thymidine incorporation was unchanged, but this does not disprove an effect of the steroid on cell proliferation at this site.
This region contains a heterogeneous cell population comprising cells with endothelial, osteoblastic, osteoclastic, and haemopoietic functions, and no attempt was made to differentiate these when counting labels. Furthermore, counts of unlabelled cells indicated that hydrocortisone had caused a significant reduction in the number of cells that populate this area.

\section{Summary}

The pattern of ${ }^{3} \mathrm{H}$-thymidine labelling was studied in normal rats and rats given hydrocortisone $5 \mathrm{mg}$. daily for 28 days. The rate of labelling in the various cell groups in bone and cartilage was measured.

Hydrocortisone depressed the level of ${ }^{3} \mathrm{H}$-thymidine uptake in synovial membrane, articular cartilage and epiphyseal growth cartilage. The steroid caused narrowing of the growth cartilage ascribed partly to the reduced number of cells per growth column, affecting particularly the hypertrophied chondrocytes, and partly to a reduction in cartilage matrix.

Impairment of cartilage absorption brought about increased density of the metaphysis in hydrocortisonetreated rats with inclusion of an excessive amount of cartilage in the provisional cancellum. The general level of cell density in the metaphysis was reduced, but the labelling index showing little alteration.

We thank Prof. D. H. Collins for advice and helpful comments. The work was supported by grants (to Prof. Collins) from the Empire Rheumatism Council and (to W. A. J. Crane) from the Medical Research Fund of the University of Sheffield. We are grateful to Mrs. J. Higginbottom for valuable technical assistance.

\section{REFERENCES}

Crane, W. A. J., and Dutta, L. P. (1963). J. Path. Bact., 86, 83.

Cronkite, E. P., Bond, V. P., Fliedner, T. M., and Rubini, J. R. (1959). Lab. Invest., 8, 263.

Dodds, G. S. (1932). Amer.J. Anat., 50, 97.

Duthie, R. B. (1962). In "Radioisotopes and Bone". A Symposium organized by C.I.O.M.S., ed. F.C. McLean, P. Lacroix, and A. M. Budy, pp. 293-313. Blackwell, Oxford.

Follis, R. H., Jr. (1951). Proc. Soc. exp. Biol. (N.Y.), 78, 723.

Friedkin, M., Tilson, D., and Roberts, D. (1956). J. biol. Chem., 220, 627.

Gall, J. G., and Johnson, W. W. (1960). J. biophys. biochem. Cytol., 7, 657.

Ghadially, F. N., and Green, H. N. (1957). Brit.J. exp. Path., 38, 100.

Howard, A., and Pelc, S. R. (1953). Heredity, 6, Suppl., p. 261. 
Hulth, A., and Westerborn, O. (1963). Virchows Arch. path. Anat., 336, 209.

Kember, N. F. (1960). J. Bone Jt Surg., 42B, 824.

Laron, Z., and Boss, J. H. (1962). Arch. Path., 73, 274.

Leblond, C. P., Messier, B., and Kopriwa, B. (1959). Lab. Invest., 8, 296.

Mirsky, A. E., and Osawa, S. (1961). In "The Cell", ed. J. Brachet and A. E. Mirsky, vol. 2, pp. 677-763. Academic Press, New York.

Reichard, P.. and Estborn, B. (1951). J. biol. Chem., 188, 839.

Rubini, J. R., Cronkite, E. P., Bond, V. P., and Fleidner, T. M. (1960). J. clin. Invest., 39, 909.

Tonna, E. A. (1961). J. biophys. biochem. Cytol., 9, 813.

Wimber, D. E. (1963). In "Cell Proliferation". A Guinness Symposium, ed. L. F. Lamerton and R. J. M. Fry, pp. 1-17. Blackwell, Oxford.

Effet de l'hydrocortisone sur l'utilisation de la thymidine, rendue radioactive par le tritium, pour la croissance squelettique du rat

RÉSUMÉ

On étudia le tableau produit par la ${ }^{3} \mathrm{H}$-thymidine chez des rats normaux et des rats traités par $5 \mathrm{mg}$. d'hydrocortisone par jour pendant 28 jours. On a mesuré le taux d'enregistrement de la radioactivité dans de différents groupes de cellules de l'os et du cartilage.

L'hydrocortisone abaissait le taux d'utilisation de la ${ }^{3} \mathrm{H}$-thymidine dans la membrane synoviale, le cartilage articulaire et le cartilage épiphysaire de croissance. Le stéroïde causait un rétrécissement du cartilage de croissance, attribué en partie au nombre réduit de cellules par colonne de croissance, affectant en particulier les chondrocytes hypertrophiés, et en partie à la réduction de la matrice cartilagineuse.

L'absorption cartilagineuse défectueuse amenait l'augmentation de la densité de la métaphyse chez des rats traités par l'hydrocortisone, avec inclusion d'une quantité excessive de cartilage dans le cancellum provisoire. Le niveau général de la densité cellulaire dans la métaphyse se trouvait diminué, mais l'indice de radioactivité (labelling index) était peu altéré.

Efecto de la hidrocortisona sobre la utilización de la timidina radioactiva para el crecimiento del esqueleto de la rata

\section{SUMARIO}

Se estudió el cuadro producido por la ${ }^{3} \mathrm{H}$-timidina en ratas normales y en ratas a las cuales se habían administrado $5 \mathrm{mg}$. de hidrocortisona al día durante 28 días. La frecuencia de las marcas (labelling) de radioactividad en varios grupos de células en los huesos y en el cartílago fué medida.

La hidrocortisona hacía bajar la tasa de utilización de la ${ }^{3} \mathrm{H}$-timidina en la membrana sinovial, el cartílago articular y en el cartílago epifisario de crecimiento. El esteroide ocasionaba un estrechamiento del cartílago de crecimiento, lo que se atribuye en parte a la reducción numérica de células en cada columna de crecimiento afectando en particular los condrocitos hipertrofiados y, en parte, a la reducción de la matriz cartilaginosa.

El deterioro de la absorpción cartilaginosa ocasionaba un aumento de la densidad de la metáfisis en ratas tratadas con la hidrocortisona, con inclusión de una cantidad excesiva de cartílago en el cancellum provisional. El nivel general de la densidad celular en la metáfisis se veía disminuido, pero el índice de radioactividad (labelling index) acusaba poca alteración. 